\title{
Postglacial Fire Frequency and ITS RELATION TO LONG-TERM VEGETATIONAL and Climatic Changes in Yellowstone Park
}

\author{
CATHY WHITLOCK $\bullet$ DEPARTMENT OF GEOGRAPHY \\ UNIVERSITY OF OREGON • EUGENE
}

\section{$\checkmark$ OBJECTIVES}

The primary research objective has been to study the vegetational history of Yellowstone and its sensitivity to changes in climate and fire frequency. To establish a sequence of vegetational changes, a network of pollen records spanning the last 14,000 years has been studied from different types of vegetation within the Park. The relationship between modern pollen rain, modern vegetation and presentday climate in the northern Rocky Mountains has been the basis for interpreting past vegetation and climate from the fossil records. Changes in fire regime during the past 14,000 years have been inferred from sedimentary charcoal and other fire proxy in lake sediments. Calibration of the fire signal is based on a study that measures the input of charcoal into lakes following the 1988 fires in Yellowstone. four parts:

The research project has been divided into

1. A study of the modern charcoal accumulation into lake sediments. At regular time intervals, we are collecting surface sediments from different water depths in lakes that lie both within the 1988 burned region and at varying distances from the burn. We are relating charcoal abundance in these samples to basin size, water depth, and fire size and proximity.
2. An analysis of fire events during the past ca. 500 years. We are examining charcoal abundance, pollen composition, and paleomagnetic characteristics at closely spaced intervals in meter-long sediment cores to determine if the stratigraphic evidence of fire correlates well with the fire chronology based on dendrological studies (Romme 1992, unpublished data).

3. An analysis of fire history from a lake with annually laminated (varved) sediments. To reconstruct fire history on an annual time scale and to extend the fire chronology beyond the limits of Lead-210 dating, we are studying a 600 -year varved record from Crevice Lake in the Northern Range.

4. An analysis of vegetational history and fire frequency of the last 14,000 years. Our current research focuses on the vegetational and fire history of the Central Plateau and southern Yellowstone region, the Bechler region, and the Northern Range.

\section{METHODS}

Detailed methodology for this research has been described in Millspaugh (1991) and Whitlock (1990), and only tasks accomplished since May 1992 are described. 
CHARCOAL ACCUMULATION FROM THE 1988 FIRES

Surface sediment samples have been taken from burned and unburned sites biannually since 1989. In August, we collected a suite of samples from Duck, Goose, Cascade, Grizzly, Dryad, and Sylvan lakes, and Lake of the Woods.

\section{FIRE HISTORY OF THE LAST CA. 500 YEARS}

One-m-long cores were obtained from Cub Creek Pond and Slough Creek Pond in August and subsamples were taken at $1-\mathrm{cm}$ intervals. Charcoal abundance and magnetic susceptibility were analyzed in short cores from Grizzly, Goose, and Cygnet lakes.

\section{FIRE HISTORY FROM A VARVED-LAKE RECORD}

A frozen-sediment core from Crevice Lake has been photographed and the laminations have been counted. Analysis of the charcoal from this core follows the thin-section method of Clark (1988). To learn these techniques, Sarah Millspaugh went to the Limnological Research Center, University of Minnesota. The procedure involves replacing the water in the core with acetone and then epoxy to harden the sediments; cutting slices of the hardened core along transverse surfaces; and grinding these slices into thin sections so that they can be mounted on glass slides for microscopic analysis. Our first efforts to impregnate the Crevice Lake core in epoxy were unsuccessful. In September, we modified the procedure and achieved good results. In the next 6 months, the rest of the core will be prepared by the epoxy method, and slabs will be sent to a commercial lab to be thin-sectioned and mounted on petrographic slides.

\section{POSTGLACIAL VEGETATIONAL AND FIRE HISTORY}

Long cores were collected from Robinson Lake in the Bechler region and Cub Creek Pond in the Yellowstone Lake drainage. Pollen analysis of a core from Loon Lake in the Bechler region is nearly completed. Charcoal and magnetic susceptibility analyses of cores taken from Cygnet Pond in 1991 are also underway.

\section{RESULTS}

The results of this research appear in several recent and forthcoming issues of Ecological Monographs (Whitlock, 1993); Ecology (Millspaugh and Whitlock, in review); Quaternary Research (Whitlock and Bartlein, 1993); Journal of Paleolimnology (Engstrom and others, 1991); and Proceedings of the National Park Service (Whitlock, in press; Millspaugh, in press). The findings have been discussed in book chapters (Whitlock and others, 1991; Thompson and others 1993), and they have been the basis for two M.S. theses (Sherrod, 1989; Millspaugh, 1991), and a Ph.D. dissertation (Millspaugh, to be completed in 1994). In addition, papers have been presented at national meetings of the Ecological Society of America, the Association of American Geographers, and the Geological Society of America and at the International Palynology Conference (e.g., Millspaugh and Whitlock Barnosky, 1990; Whitlock and Bartlein, 1991). Some specific results of the last six months are discussed below:

\section{CHARCOAL ACCUMULATION FROM THE 1988 FIRES}

Charcoal profiles for Duck, Goose, Cascade, and Grizzly lakes for March 1992 are shown in Figure 1. Charcoal particles between 125 and 250 microns have proven to be a reliable indicator of local catchment fire. Charcoal quantities have increased in the sediments of burned lakes and unburned lakes between 1989 and 1992 . The initial source of charcoal was airborne fall-out during the fire, and this is still the primary component in unburned watersheds. Lakes with burned catchments have received additional charcoal from two sources: (1) slopewash processes and (2) sediment focusing of material from shallow water to deep water. It is probable that quantities of charcoal from these secondary sources will continue to increase as charcoal is introduced from burned slopes and moved from shallow to deep water.

Paleoecologists generally collect cores in deep water at the center of the lake. Thus, information on the lag between a fire and its registration as a charcoal peak in deep-water sediments is of critical importance in paleoecologic studies. The type of vegetation that burned, as well as the characteristics of the lake catchment and 

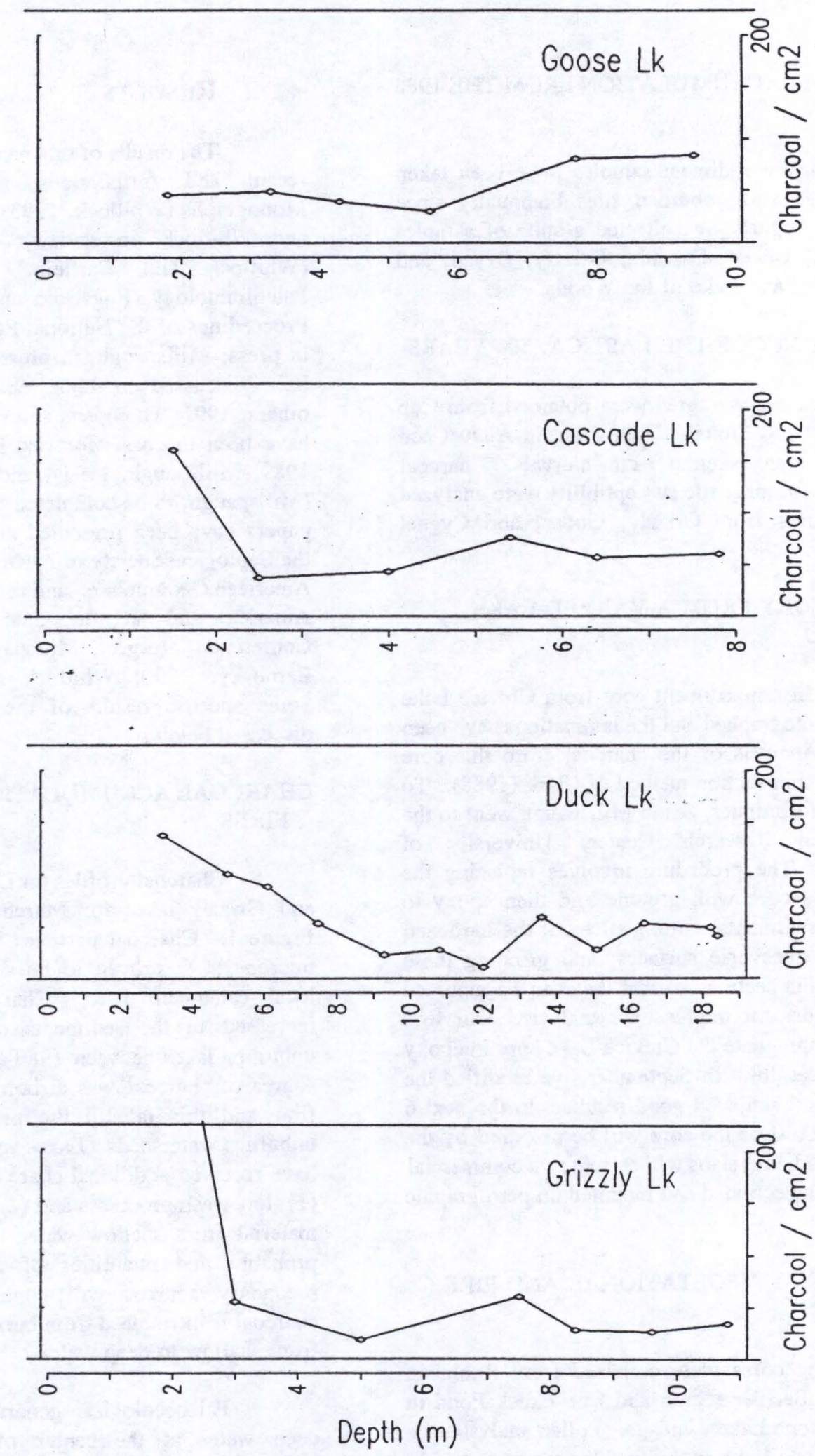

Figure 1. Charocoal abundance in the surface sediments in March 1992. At each site, samples were collected along a transect from shallow to deep water. 
bathymetry seem to be significant in determining the amount of charcoal in deep-water sediments. As an example, Goose Lake lies in a low-gradient catchment that was covered by open Pinus contorta forest and $95 \%$ burned by ground fire in 1988. Despite the size of the catchment fire, Goose Lake contains the lowest amount of sedimentary charcoal of any of the burned sites. We think that the type of forest produced little charcoal (see Renkin and Despain 1991) and that the low gradient of the catchment has limited the amount of charcoal to the site through secondary processes.

In contrast, the catchment of Duck Lake supported forest of Picea, Abies, and Pinus contorta and a dense shrub understory. About $60 \%$ of the catchment burned in 1988 as a mixed canopy/ground fire. The amount of charcoal in lake sediments was higher than other sites in 1989 and charcoal quantities in deep-water sediments have increased since 1988. Our data suggest that the burning of this forest produced abundant charcoal and that steep slopes and bathymetry have allowed charcoal to be introduced to the system through erosion and sediment focusing.

At present, quantities of charcoal in deepwater sediments are not above the level of significance that would indicate a local fire event at either Goose or Duck lakes. We hypothesis that charcoal abundance in the sediments will continue to increase in burned lakes in the next few years and that charcoal evidence of a fire event in 1988 will be more obvious in the future.

\section{FIRE HISTORY OF THE LAST CA. 500 YEARS}

Charcoal and magnetic susceptibility have been analyzed in lead-210-dated short cores from Duck, Mallard, and Dryad lakes (Millspaugh and Whitlock, in review). Stratigraphic levels that feature abundant charcoal and high values of magnetic susceptibility are interpreted as times of local catchment fire accompanied by significant erosion. Duck, Mallard, and Dryad lakes all record major fires between ca. $1690-1750$, a period that was also identified in the fire chronology developed by Romme and Despain (1989) from dendrologic records. Fire events occurred on a 40-60 year frequency from ca. 1500 to ca. 1750 , but they have been relatively rare since that time.
Charcoal and magnetic susceptibility measurements from Grizzly Lake, Goose Lake, and Cygnet Lake have been completed, and samples for lead-210 dating have been submitted. The profiles show changes in charcoal and clastic material that record past fires and erosion at each site (Figure 2). All the sites record the 1988 fire and a fire at ca. 30$35 \mathrm{~cm}$ depth in the core, which we think dates to ca. 1700. The preliminary data suggest changes in the longer fire recurrence interval in the last century.

Pollen percentages associated with historic fire events at Duck Lake show noticeable variations in the abundance of conifer pollen and total herb pollen. The increase in total herb pollen associated with fire events may reflect an increase in herbaceous taxa that rapidly colonize a burned area. The fluctuations in coniferous pollen probably reflect the burning of late-successional spruce, fir, and pine forests.

\section{A FIRE HISTORY FROM VARVED SEDIMENTS}

High resolution photographs have been taken of the Crevice Lake core, and ca. 600 varves layers have been counted. This core is being subsampled for charcoal; no results are available at this time.

\section{STUDY OF POSTGLACIAL VEGETATION AND FIRE HISTORY}

As part of a study of the vegetation and climate history of the Bechler region, a $12.3 \mathrm{~m}$ core from Loon Lake (Targhee National Forest) was collected in the summer 1991. Pollen analysis of the core suggests that Populus tremuloides and Hapoxylon-type Pinus have been components of the vegetation throughout the Holocene. The bottommost sediments at the site contain abundant Picea and herb pollen, which suggests a period of spruce parkland vegetation. Comparison with other radiocarbon-dated records in Yellowstone indicates that the Loon Lake core spans the last ca. 11,000 years. Radiocarbon dates will be submitted this fall.

A $6.5 \mathrm{~m}$ core was taken from the floating mat at Robinson Lake to study the history of the wetland endemics there. At the base of the core was Mazama ash, suggesting that the site is ca. 7000 years old. Further cores will be collected next summer. 


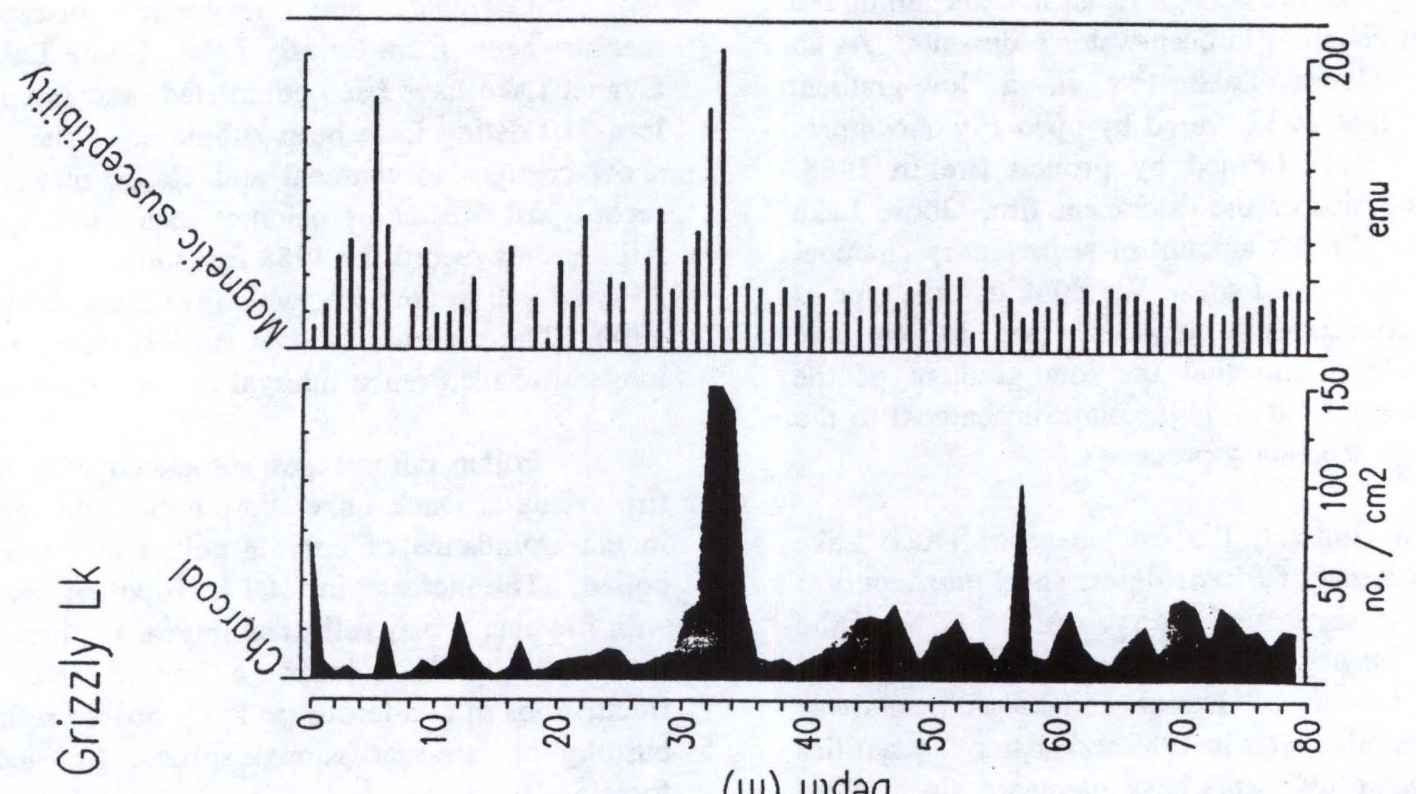

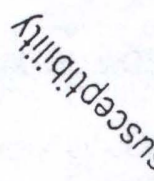

(u) $41 \mathrm{~d} \partial 0$

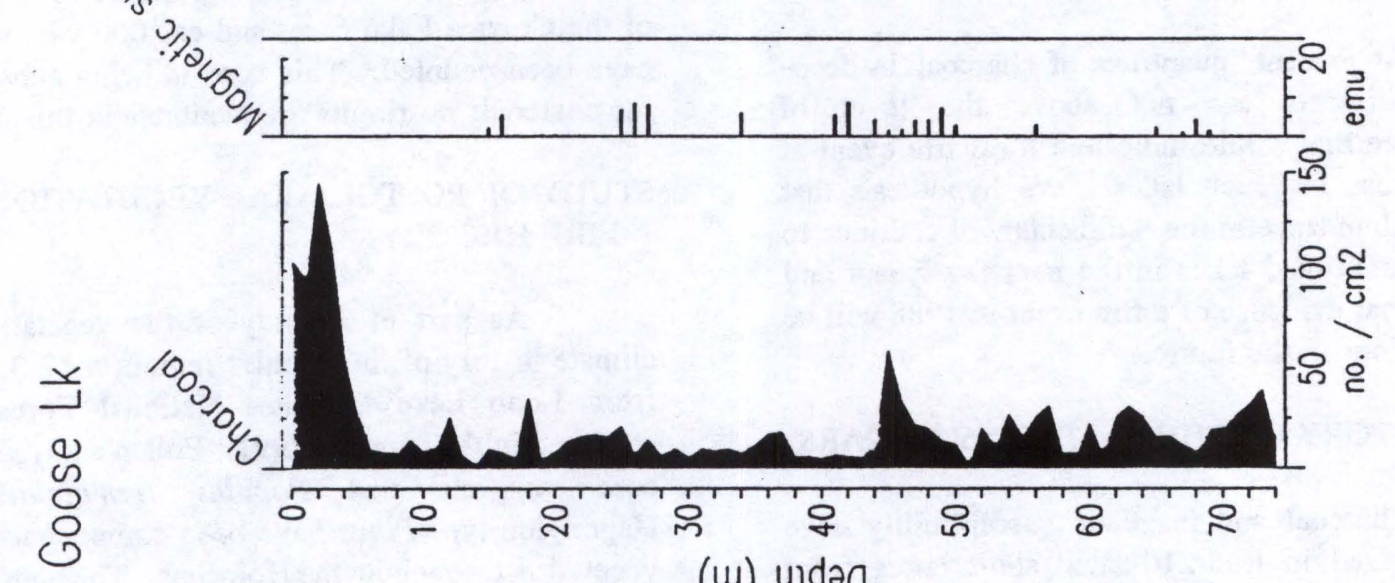

"I" $/ 1 / \sigma^{2}$

(u) $47 \mathrm{~d} \partial 0$

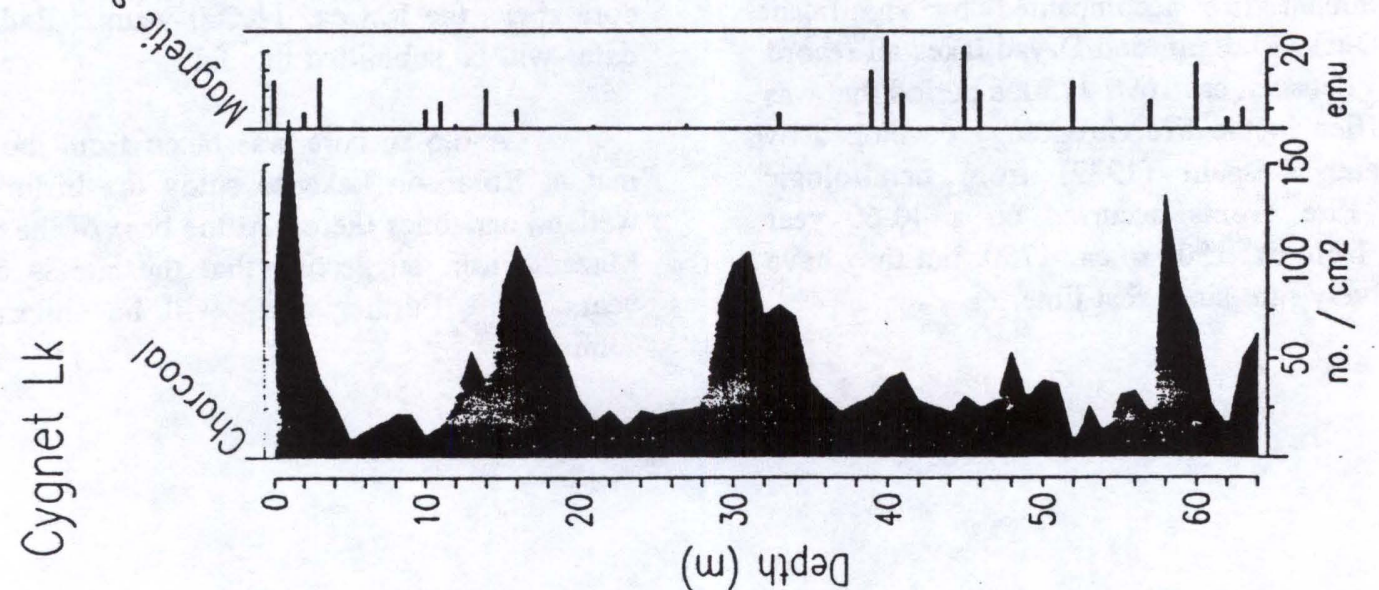

马ै

(ii) 41də0 
Charcoal and pollen from Cygnet Lake are under study to provide a detailed 14,000-year recordof fire history and vegetational change from the Central Plateau. No results are available at this time. Cores collected from Cub Creek Pond are currently being subsampled for pollen analysis. This site will provide a detailed environmental reconstruction for NPS archeological investigations along the shores of Yellowstone Lake.

\section{PROBLEMS ENCOUNTERED DURING PROJECT}

We assumed that charcoal would be well recorded in lake sediments in the first months after the 1988 fires. This assumption has proven false; charcoal amounts have been gradually increasing in lake surface sediments during the last four years, and there is every reason to think the trend will continue in the future. Because the rate of charcoal accumulation is slower than we anticipated, we plan to sample the sites once a year rather than biannually as originally proposed.

Charcoal analysis of the Crevice Lake has been more complicated and costly than anticipated. Now that we have mastered the epoxy impregnation technique, we should be able to make more progress.

\section{FUTURE WORK IN THE CONTRACT YEAR}

Charcoal samples collected in 1992 will be analyzed from all the study sites. Short cores from Grizzly, Goose, and Cygnet lakes will be lead-210 dated. The varve record from Crevice Lake will be subsampled and analyzed for charcoal. Pollen analysis on Loon Lake will be completed. Pollen and charcoal analysis will be initiated on the long cores collected at Cygnet Lake and Cub Creek Pond.

\section{$\checkmark$ ACKNOWLEDGEMENTS}

I wish to thank John Varley and Don Despain (Yellowstone National Park) for their continued support and stimulating discussions of this project. Jennifer Whipple and Rick Hutchinson (Yellowstone National Park) helped core Robinson Lake. I also thank Ron Jones, Lynn Kaeding, Dan Mahoney, Dan Carty, and Glen Boltz of the USFWS for their tremendous logistical assistance.

\section{$\checkmark \quad$ LITERATURE CITED}

Clark, J. S. 1988. Stratigraphic charcoal analysis on petrographic thin sections: applications to fire history in northwestern Minnesota. Quaternary Research 30:81-91.

Engstrom, D. R., C. Whitlock, S. C. Fritz, and H. E. Wright, Jr. 1991. Recent environmental changes inferred from the sediments of small lakes in Yellowstone's Northern Range. Journal of Paleolimnology 5:139-174.

Millspaugh, S. H. 1991. A record of fire in the sediments of small lakes from Yellowstone National Park. M.S. Thesis. Department of Geology and Planetary Science, University of Pittsburgh.

in press. Records of fire preserved in lakes sediments from the Central Plateau of Yellowstone National Park. National Park Service Transactions and Proceedings.

Millspaugh, S. H., and C. Whitlock. in review. A 500-year fire history based on lake sediment records in Yellowstone National Park. Ecology.

Millspaugh, S. H., and C. Barnosky Whitlock. 1990. Calibrating modern charcoal records to reconstruct prehistoric fires in Yellowstone National Park (abstract). Proceedings of the Ecological Society of America Annual Meeting, Snowbird.

Renkin, R. A., and D. G. Despain. 1991. Fuel moisture, forest type, and lightning-caused fire in Yellowstone National Park. Canadian Journal of Forest Research 22:3745.

Romme, W. H. 1982. Fire and landscape diversity in subalpine forests of Yellowstone National Park. Ecological Monographs 52:199-221.

Romme, W. H. and D. G. Despain. 1989. Historical perspective on the Yellowstone fires of 1988. Bioscience 39:695-699. 
Sherrod, B. L. 1989. Paleolimnology of Alder Lake and its implications for Holocene tectonics in Yellowstone National Park, Wyoming. M.S. Thesis, Department of Geology and Planetary Sciences, University of Pittsburgh.

Thompson, R. S., G. Whitlock, S. P. Harrison, W. G. Spaulding, and P. J. Bartelein. in press. Climatic changes in the western United States since $18,000 \mathrm{yr}$ b.p. In: H. E. Wright, Jr., J. E. Kutzbach, W. F. Ruddiman, F. A. Street-Perrott, and T. Webb III, eds. Global climates since the Last Glacial Maximum. University of Minnesota Press, Minneapolis.

Whitlock-Barnosky, C. $1990 . \quad$ Long-term vegetational changes at contrasting elevations in the northwestern U.S. (abstract). Proceedings of the Ecological Society of America, Snowbird.

Whitlock, C. 1990. Late-Quaternary vegetational and climatic history of the Yellowstone/Grand Teton region. UW-NPS Research Center Final Report.

- 1992. Vegetational and climatic history of the northwestern U.W. since 20 ka (abstract). Proceedings of the VIII International Palynological Conference, Aixen-Provence, France.

1993. Long-term vegetational response to climatic change and edaphic conditions in Yellowstone National Park. National Park Service Transactions and Proceedings.
1993. Postglacial vegetational and climate of Grand Teton and southern Yellowstone National Parks. Ecological Monographs.

Whitlock, C., and P. J. Bartlein. 1991. Analysis of the patterns of Holocene climatic change in the Northern Rocky Mountains (abstract). Proceedings of the Geological Society of America Annual Meeting, San Diego.

Whitlock, C., and P. J. Bartlein. 1993. Spatial variations of Holocene climatic change in the Northern Rocky. Mountains. Quaternary Research. In press.

Whitlock, C. and S. H. Millspaugh. 1991. Development of a fire history in Yellowstone National Park (abstract). Proceedings of Association of American Geographers Annual Meeting, Miami.

Whitlock, C., S. C. Fritz, and D. R. Engstrom. 1991. A prehistoric perspective on Yellowstone's Northern Range. In: R. B. Keiter and M. S. Boyce, editors. The Greater Yellowstone Ecosystem: Redefining America's Wilderness Heritage, pp. 289305. Yale University Press. 